\title{
Comparison of Financial Leverage Ratio before and after the Use of Off- Balance Sheet Financing in Firms Listed in the Tehran Stock Exchange
}

\author{
Mehdi Mardani ${ }^{1 *}$, Reza Fallah ${ }^{1}$ \\ ${ }^{1}$ Department of Accounting, Ayatollah Amoli Branch, Islamic Azad University, Amol, IRAN
}

*Corresponding Author: R.Falaha@yahoo.com

Citation: Mardani, M. and Fallah, R. (2018). Comparison of Financial Leverage Ratio before and after the Use of Off-Balance Sheet Financing in Firms Listed in the Tehran Stock Exchange. Dutch Journal of Finance and Management, 2(2), 53. https://doi.org/10.29333/djfm/5829

Published: September 28, 2018

\begin{abstract}
The aim of this study was to compare the proportion of financial leverage in companies before and after the use of off-balance sheet financing in firms listed in the Tehran Stock Exchange. The research method was causal-comparative descriptive. The population was all the accepted companies in Tehran Stock Exchange (cars and car fragments, petrochemicals, petroleum products, cement, pharmaceutical, home and sugar appliances) between years of 2010 and 2014 that 87 companies were selected at random. Data were analyzed using independent t-test. Results showed that the average financial leverage for companies which have used off-balance sheet financing was equal to 0.6398 and the average financial leverage for companies that did not use off-balance sheet financing has been equal to 0.5612 . Therefore, there was no significant difference between averages of the two samples. Other results showed that the average of return on investment (ROI) ratio in companies that used off-balance sheet financing had no significant statistical reference with an average of return on investment (ROI) ratio in companies that did not use off-balance sheet financing. As well, the average of return on owner's equity (ROE) ratio in companies that have used off-balance sheet financing had no significant statistical difference with the average of return on owner's equity (ROE) ratio in companies that have not used off-balance sheet financing.
\end{abstract}

Keywords: financial leverage, stock exchange, board of directors

\section{INTRODUCTION}

Berger and Youdell (1998) have expressed the capital structure as the balance between debt and assets, the nature of assets and composition of corporate's debt. Ferrocene and Harvey (1991) introduced the capital structure as a general claim in the company's assets (quoted by Sung and Bae, 2009). Optimal capital structure is the capital structure that makes optimal balance between risk and return and thereby, causes to reduce the cost of capital and to maximize the stock and the value price of the company (Khodaie-valezaqard and Yahyaie, 2010). Several factors affect the capital structure decisions. The first factor is company's business risk or the risk associated with the assets in case of not to use debts. The more level of business risk in a company would cause the less optimal debt ratio. The second key factor is the tax status of the company. The most important use of debt is acceptability of its return cost by the Ministry of Economy and Finance which reduces the effective cost of debt (Hasan and Butt, 2009). The third factor is capital budgeting (Maquieira et al., 2012). Several researchers have described a series of psychological factors in connection with the causes of the phenomenon of overreaction by investors and have put this problem in the behavioral-financial field. They point to the two psychological biases of investors when making investment decisions in the interpretation of the overreaction. The one is an excessive confidence and the other is 
success attributed to oneself. An excessive confidence means that people are interested to trust their skills, their abilities and their knowledge too much. An excessive confidence about the stock that it is difficult to determine their value is stronger (Faramarzi and Pormosa, 2014). As a result of the psychological bias of the success attributed to oneself, investors have attributed the good results to their skills and unexpected adverse outcomes to their bad luck and they have confided to their skills in selecting the stock completely. The aim of this study was to compare the proportion of financial leverage in companies before and after the use of off-balance sheet financing in firms listed in the Tehran Stock Exchange.

\section{METHODOLOGY}

The research method was descriptive and causal-comparative. The population was all the accepted companies in Tehran Stock Exchange (cars and car fragments, petrochemicals, petroleum products, cement, pharmaceutical, home and sugar appliances) between years of 2010 and 2014 that 87 companies were selected randomly. The companies with the following conditions were participated in the study.

1. Those that their financial period conduces to the end of March.

2. Those that have been accepted in the Tehran Stock Exchange prior to 2013.

3. Those that are not among the mediation, financing, leasing and insurance companies.

4. Those that their needed financial information is available.

5. Those that are not among companies with the initial supply of the stock.

Following regression model was used to achieve the research goals.

off - balance sheet financing $i t=\alpha_{0}+\alpha_{1} R O I_{i t}+\alpha_{2} R O E_{i t}+\alpha_{3} R O A_{i t}+\alpha_{4} \operatorname{Lev}_{i t}+\alpha_{5} \frac{P}{E_{i t}}+\alpha_{6} \operatorname{Size}_{i t}+\varepsilon_{i t}$

off - balance sheet financing $i t$ : Off-balance sheet financing in the studied years

$R O I_{i t}$ : Return on investment (ROI) ratio in the studied years

$R O E_{i t}$ : Return on owners' equity (ROE) ratio in the studied years

$R O A_{i t}$ : Return on assets (ROA) ratio in the studied years

$L e v_{i t}$ : Financial leverage ratio in the studied years

$P / E_{i t}$ : Price to earnings per share ratio of companies in the studied years

Size $_{i t}$ : The size of the companies in the studied years

According to the study of Glen and Singh (2004), the criterion of profitability index may affect on the relationship between capital structure and other variables. Profitability indices involve return on investment, return on owner's equity and return on assets that are calculated as follows.

A) Return on investment:

B) Return on owners' equity

$$
R O I_{i, t}=\frac{\text { Profit and loss before taxes (gross) }}{\text { Total assets }}
$$

$$
R O E_{i, t}=\frac{\text { Profit and loss after taxes (net profit) }}{\text { equity }}
$$

C) Return on assets

$$
R O A_{i, t}=\frac{\text { Profit and loss after taxes (net profit) }}{\text { Total assets }}
$$

D) Financial leverage ratio:

To calculate the financial leverage ratio of firm $i$ in year $t$, we have (Maquieira et al., 2012):

$$
\operatorname{Lev}_{i, t}=\frac{\text { The book value of total debts }}{\text { The book value of total assets }}
$$

E) Price to earnings per share ratio:

It will be proceeded to calculate the ratio of stock price to earnings per share of the firm $\mathrm{i}$ in year $\mathrm{t}$ as follows. Price ratio (3.5) Earnings per share

$$
\text { PEration }_{i, t}=\frac{\text { Price per share }}{\text { Earnings per share }}
$$

Off-balance sheet financing of the firm $i$ in year $t$ was measured using rental costs disclosed in the notes to the financial statements of companies listed in Tehran Stock Exchange (Faramarzi and Pormosa, 2014). Independent $\mathrm{t}$-test was used to analyze the data. In all analyzes, the significant level was considered as $\mathrm{p}<0.05$. 
Dutch Journal of Finance and Management, 2(2), 53

Table 1. Results of t-test

\begin{tabular}{|c|c|c|c|c|c|c|c|c|}
\hline \multirow{3}{*}{$\begin{array}{l}\text { Financial } \\
\text { leverage }\end{array}$} & \multicolumn{2}{|c|}{$\begin{array}{c}\text { Levene's Test for } \\
\text { Equality of Variances }\end{array}$} & \multicolumn{6}{|c|}{ T-test for Equality of Means } \\
\hline & \multirow{2}{*}{$\mathbf{F}$} & \multirow{2}{*}{ Sig. } & \multirow{2}{*}{$\mathbf{T}$} & \multirow{2}{*}{$\begin{array}{l}\text { Sig. (2- } \\
\text { tailed) }\end{array}$} & \multirow{2}{*}{$\begin{array}{c}\text { Mean } \\
\text { Difference }\end{array}$} & \multirow{2}{*}{$\begin{array}{l}\text { Std. Error } \\
\text { Difference }\end{array}$} & \multicolumn{2}{|c|}{$\% 95$ Confidence Interval of the Difference } \\
\hline & & & & & & & Lower & Upper \\
\hline $\begin{array}{c}\text { Variance equality } \\
\text { hypothesis }\end{array}$ & 4.329 & 0.038 & 2.811 & 0.005 & 0.07862 & 0.02793 & 0.02361 & 0.13362 \\
\hline $\begin{array}{c}\text { Variance inequality } \\
\text { hypothesis }\end{array}$ & & & 2.679 & 0.008 & 0.07862 & 0.02937 & 0.02072 & 0.13651 \\
\hline
\end{tabular}

Table 2. Results of independent t-test

\begin{tabular}{|c|c|c|c|c|c|c|c|c|}
\hline \multirow{3}{*}{ ROI } & \multicolumn{2}{|c|}{$\begin{array}{c}\text { Levene's Test for } \\
\text { Equality of Variances }\end{array}$} & \multicolumn{6}{|c|}{ T-test for Equality of Means } \\
\hline & \multirow{2}{*}{$\mathbf{F}$} & \multirow{2}{*}{ Sig. } & \multirow{2}{*}{$\mathbf{t}$} & \multirow{2}{*}{$\begin{array}{l}\text { Sig. (2- } \\
\text { tailed) }\end{array}$} & \multirow{2}{*}{$\begin{array}{c}\text { Mean } \\
\text { Difference }\end{array}$} & \multirow{2}{*}{$\begin{array}{l}\text { Std. Error } \\
\text { Difference }\end{array}$} & \multicolumn{2}{|c|}{$\% 95$ Confidence Interval of the Difference } \\
\hline & & & & & & & Lower & Upper \\
\hline $\begin{array}{c}\text { Variance equality } \\
\text { hypothesis }\end{array}$ & 1.998 & 0.158 & -0.402 & 0.688 & -0.01100 & 0.02739 & -0.06487 & 0.04288 \\
\hline $\begin{array}{c}\text { Variance inequality } \\
\text { hypothesis }\end{array}$ & & & 0.300 & 0.765 & -0.01100 & 0.03672 & -0.08368 & 0.06168 \\
\hline
\end{tabular}

Table 3. Results of independent t-test

\begin{tabular}{|c|c|c|c|c|c|c|c|c|}
\hline \multirow{3}{*}{ ROE } & \multicolumn{2}{|c|}{$\begin{array}{l}\text { Levene's Test for } \\
\text { Equality of Variances }\end{array}$} & \multicolumn{6}{|c|}{ T-test for Equality of Means } \\
\hline & \multirow{2}{*}{ F } & \multirow{2}{*}{ Sig. } & \multirow[b]{2}{*}{ t } & \multirow{2}{*}{$\begin{array}{l}\text { Sig. (2- } \\
\text { tailed) }\end{array}$} & \multirow{2}{*}{$\begin{array}{c}\text { Mean } \\
\text { Difference }\end{array}$} & \multirow{2}{*}{$\begin{array}{l}\text { Std. Error } \\
\text { Difference }\end{array}$} & \multicolumn{2}{|c|}{$\% 95$ Confidence Interval of the Difference } \\
\hline & & & & & & & Lower & Upper \\
\hline $\begin{array}{c}\text { Variance equality } \\
\text { hypothesis }\end{array}$ & 3.373 & 0.067 & -1.021 & 0.308 & -1.12070 & 1.09749 & -3.27926 & 1.03785 \\
\hline $\begin{array}{c}\text { Variance inequality } \\
\text { hypothesis }\end{array}$ & & & -1.500 & 0.135 & -1.12070 & 0.74734 & -2.59268 & 0.35127 \\
\hline
\end{tabular}

\section{RESULTS}

Results of Kolmogorov-Smirnov test showed normal distribution of the data $(\mathrm{p}>0.05)$. According to the fact that the average financial leverage for companies which have used off-balance sheet financing was equal to 0.6398 and the average financial leverage for companies that have not used off-balance sheet financing has been equal to 0.5612, therefore, there was no significant difference between the averages of two samples. Commenting on the result of this assumption, it can be concluded that the average ratio of the book value of total debt to book value of total assets in companies that used off-balance sheet financing had significant statistical difference with the average ratio of the book value of total debt to book value of total assets in companies that did not use off-balance sheet financing.

The average ratio of gross profit to total assets (ROI) in companies that used off-balance sheet financing was compared with an average ratio of gross profit to total assets (ROI) in companies that did not use off-balance sheet financing using independent t-test. Results are represented in Table 2. Given that the average (ROI) for companies that have used off-balance sheet financing was equal to 0.2125 and for companies that have not used off-balance sheet financing was equal to 0.2235 , so the average of two samples did not differ significantly. It can be concluded that the average ratio of gross profit to total assets (ROI) in companies that used off-balance sheet financing had no significant difference with an average ratio of gross profit to total assets (ROI) in companies that did not use off-balance sheet financing.

The average ratio of net profit to total equity (ROE) in companies that used off-balance sheet financing was also compared with an average ratio of net profit to total equity (ROE) in companies that did not use off-balance sheet financing. Given that the average (ROE) for companies that have used off-balance sheet financing was equal to 0.8513 and for companies that have not used off-balance sheet financing was equal to 0.2694 (Table 3), it can be concluded that the average ratio of net profit to total equity (ROE) in companies that used off-balance sheet financing had no significant difference with an average ratio of net profit to total equity (ROE) in companies that did not use off-balance sheet financing.

\section{DISCUSSION AND CONCLUSION}

The aim of this study was to compare the proportion of financial leverage in companies before and after the use of off-balance sheet financing in firms listed in the Tehran Stock Exchange. Results showed that the average 
financial leverage for companies which have used off-balance sheet financing was equal to 0.6398 and the average financial leverage for companies that did not use off-balance sheet financing has been equal to 0.5612. Therefore, there was no significant difference between averages of the two samples. It can be concluded that the average ratio of the book value of total debt to book value of total assets in companies that used off-balance sheet financing had significant statistical difference with the average ratio of the book value of total debt to book value of total assets in companies that did not use off-balance sheet financing. Other findings also showed that the average ratio of gross profit to total assets (ROI) in companies that used off-balance sheet financing had no significant difference with an average ratio of gross profit to total assets (ROI) in companies that did not use off-balance sheet financing. As well, other results showed that the average ratio of net profit to total equity (ROE) in companies that used offbalance sheet financing had no significant difference with an average ratio of net profit to total equity (ROE) in companies that did not use off-balance sheet financing. The main objective of the managers in the use of offbalance sheet financing was to reduce proportions of debt and equity and resulting in increment of profitability and stock price. Results of previous studies showed that off-balance sheet financing fans tended to provide background for increasing stock prices using the lack of transparency and insufficient knowledge of shareholders. Managers who used this method were also claimed to act in accordance with the accounting principles and accepted standards, while researches which have been done on the basis of ethical approach implied that the they use these principles and standards in order to mislead the users from the information and to hide debt in order to illustrate the company's situation and profitability as better in the use of off-balance sheet financing. Investors have considered increment of nicety in financial ratios and profitability ratios in the company as a positive sign and then, predict the company's future profitability optimistic and vice versa they know the reduction in nicety of financial ratios and profitability ratios in the company as a negative sign and expect the company's future profitability as pessimistic.

\section{REFERENCES}

Faramarzi, J. and Pormosa, A. (2014). Study of the impact of off-balance sheet financing on equity in the firms listed in the Tehran Stock Exchange. Quarterly journal of accounting science and management auditing, 12.

Glen, J. and Singh, A. (2004). Comparing capital structures and rates of return in developed and emerging markets. Emerging Markets Review, 5, 161-192. https://doi.org/10.1016/j.ememar.2004.01.001

Hasan, A. and Butt, S. (2009). Impact of ownership structure and corporate governance on capital structure of Pakistani listed companies. International journal of business and management, 4, 50-57. https:// doi.org/10.5539/ijbm.v4n2p50

Khodaie-valezaqard, M. and Yahyaie, M. (2010). Evaluation of the relationship between financial reporting quality and efficiency of investment in companies listed in Tehran Stock Exchange. Management accounting, 3(5), 1-15.

Maquieira, C. P., Preve, L. A. and Sarria-Allende, V. (2012). Capital budgeting, cost of capital and capital structure: and distinctive features in Latin America. Emerging markets review, 13, 118-148. https://doi.org/10.1016/j.ememar.2011.11.001

Sung, C. and Bae (2009). On the interactions of financing and investment decisions. Managerial finance, 35(8), 691699. https://doi.org/10.1108/03074350910967231 